Modern veterinary hospitals require elaborate design and equipment and cannot usually be provided by the private practitioner. Under the schemes now envisaged, they will be managed in such a way that whole-time staffs are available, and private practitioners and specialists will co-operate in the care of the patients. At the same time, the aim is to organise cadres of trained animal nurses and technical assistants, probably coupled with a system of training, certification and registration.

Since the Trust was inaugurated in 1942, forty-eight undergraduates have been awarded scholarships or studentships in the United Kingdom and Eire. Deserving students who are well embarked on their studies, but have suffered an adverse change in their financial circumstances and, otherwise, would have been unable to proceed with their studies, have been assured an opportunity of obtaining their qualifications. $£ 7,320$ has been expended on the assistance of such students. In addition, nineteen Evans Final Year Studentships have been awarded to the best students in the previous four years of study at the respective veterinary colleges.

The Wellcome Trust, the Goldsmiths Company, Messrs. Cooper, MeDougall and Robertson, Ltd., the British Oil and Cake Mills, Ltd., and Imperial Chemical Industries, Ltd., have provided funds for research fellowships held under the Trust. Details have been given of eleven such fellowships now held by British veterinary and other science graduates for studies of a very varied nature at scientific institutions in the United Kingdom and the United States of America.

At the annual general meeting of the Trust, held in October 1947, a detailed account of progress was given. It was attended by an influential body of people, including, in addition to the officers of the Trust, senior representatives of the livestock and other interests concerned, such as the secretary of the Agricultural Research Council, the president of the Royal Agricultural Society of England, the president of the Royal College of Veterinary Surgeons, the president of the National Veterinary Medical Association of Great Britain and Ireland, and many others. Influential committees have been appointed to cover the several special interests concermed. The Duke of Norfolk is president and the Duke of Beaufort is the honorary treasurer. Dr. W. R. Wooldridge is the scientific director. The income for the year ended August 31, 1946, was $£ 39,240$ and the expenditure was $£ 21,558$. The assets amounted to $£ 137,410$, with a mortgage of $£ 20,000$ on property held.

Complementary to the scientific, educational and other activities, an organisation is being developed for acquainting the public throughout the country with what is being done and for collecting the money required for the operations of the Trust, the address of which is 232-35 Abbey House, Victoria Street, London, S.W.l.

\section{VEGETABLE TANNING MATERIALS OF INDIA}

$\mathrm{T}$ HE Forest Research Institute at Dehra Dun has issued a series of Forest Leaflets dealing with the vegetable tanning materials of India (Nos. 72, 73, 74,75 and 76 , published in 1944-45).

Leaflet No. 72 dealt with a general survey of the vegetable tanning materials of India (Part 1); No. 73 with the same heading (Part 2), the tanning materials of avaram (Cassia auriculata); No. 75, the tanning materials obtained from the well-known Myrobalan (Terminalia chebula).

In Leaflet No. 74 (Civil and Military Press, Prem Nagar, Dehra Dun, 1945) the tree dealt with is the Acacia arabica, the best-known vernacular names of which are babul, kikar and babar. The tree has several varieties. The information given deals with the bark and the pods, their tanning content and its variation with age, part of the plant from which obtained, and the locality of its tree growth. Information is also given on the yield obtained from the bark and the pods, the quantities of bark used and its origin and price, the methods of collection and preparation for the market; the tanning properties and manufacture of the extract are also discussed.

Sone data interesting to the forester are given with reference to the sylviculture of this tree, and the use of the bark and the timber are briefly dealt with. For a long period babul bark was one of the most firmly established tanning materials of India. It is now said to be losing its ground owing to two factors: it is not marketed as satisfactorily as its chief competitor, wattle bark, and there has been a failure in replacing by replanting trees as fast as they have been felled. Investigations on a wider scale are being carried on into some of these points.

In Leaflet No. 76, the black wattle (Acacia molissima) is discussed, with notes on other wattles growing in India, and their tanning content. In view of the remarks already made about Acacia arabica, this leaflet affords some valuable indications from various analyses made, such as variations in tanning content and, for black wattle, the yield of bark in South Africa and Java and the probable yield in India. Methods of collection and preparation for the market, tanning properties and manufacture of the extract are dealt with, and statistics of South African production, Indian imports and prices, and world use of wattle and other tanning materials are given. It is concluded that Indian-grown wattle could be made of equal tanning value to the South African bark, but more research is necessary.

The value of these researches into vegetable tanning materials is of obvious importance, since there are those who consider that this type of tanning material will always be superior to the chemical tannings.

\section{FORTHCOMING EVENTS}

(Meetings marked with an asterisk * are open to the public)

\section{Monday, February 16}

EUGENIos Society (at Manson House, 26 Portland Place, London, W.1), at 5 p.m.-Mr. W. Russell Brain: "Some Reflections on Genius" (Galton Lecture for 1948).*

ROYAL PHYSIOAL SOOIETY OF EDINBURGH (at the Royal Scottish Geographical Society, Synod Hall, Castle Terrace, Edinburgh), at 5.15 p.m. - Prof. C. H.' Waddington, F.R.S. : "Animal Development" MANCHRSTER LITERART AND PHILOSOPHICAL SOCIRTY (at the
University, Manchester), at 5.30 p.m.-Prof. R. E. Lane: "National Industrial Life and the Doctor" (Percival Lecture).*

SOCIETY OF CHEMTCAL INDUSTRY, LONDON SFOTION (at the Royal Institution, Albemarle Street, London, W.1), at 6.30 p.m.-Mr. H. W. Institution, "Abemarle : "Water, a National Asset"' (Jubilee Memorial Lecture).

\section{Tuesday, February 17}

SOCIETY OF CHEMTCAI INDUSTRY, FOOD GROUP (joint meeting with the MANCHESTRE SECTIONS of the SOCIETY OF CHEMTCAL INDUSTRY and the ROYAL INSTITUTE OF CHEMISTRY, at the Gas Showrooms, Town Hall Annexe, Manchester), at 10 a.m.-Opening by Dr. Norman C. Wright of the Ministry of Food B.I.O.S. Exhibition; at 10.30 a.m.-Mr. F. C. White : "New Developments in the German Dairy Industry"; Mr. H. J. Bunker: "Wartime Production of Food Yeast in Germany"; at 2.30 p.m.-Mr. J. F. Hearne: "German gents". 